\title{
ERROR THEORY, UNBELIEVABILITY, AND THE NORMATIVE OBJECTION
}

\author{
Daniele Bruno
}

7 HE ERROR THEORY is the view that normative judgments are beliefs that ascribe normative properties, but that these properties do not exist. AcL cording to the Error Theory, all of these judgments are therefore false. ${ }^{1}$ One of the most formidable challenges to this theory is the Normative Objection. The idea behind this objection, most forcefully put forward by Ronald Dworkin and Thomas Nagel, is simple. ${ }^{2}$ If we compare the plausibility of the Error Theory, in light of the most convincing arguments in favor of it, with the plausibility of some of our most deeply held normative judgments, we should come down firmly in favor of our normative judgments. To put the point differently: if we are to either believe that the Error Theory is true or that it is not true that we ought not to torture children for fun, then the only reasonable conclusion to draw is that the Error Theory is false.

In his book Unbelievable Errors, Bart Streumer has recently offered a novel and powerful defense of the Error Theory against this objection. He grants that our most deeply held normative judgments appear a lot more plausible than the Error Theory, to the extent that it seems bizarre to give them up in favor of it. But, he argues, this is not because the Error Theory is false. Instead, or so Streumer claims, it is because we cannot believe the Error Theory that it seems implausible when viewed against the background of our firmly held normative beliefs.

Though this Unbelievability Thesis is certainly highly controversial, I will not attempt to challenge it in what follows. Instead, I will argue that even if Streumer is correct in claiming that we cannot believe the Error Theory, this helps little to deflect the force of the Normative Objection. As I shall show, we can challenge the soundness of the main arguments that Streumer fields in support of the Error Theory through a kind of Undermining Normative Objection without appealing to

1 Important defenders of encompassing Error Theories include Olson (Moral Error Theory) and Streumer (Unbelievable Errors), though only the latter is explicit about it also extending to epistemic normativity.

2 See Dworkin, "Objectivity and Truth"; Nagel, The Last Word. 
the plausibility of the theory as a whole. I shall proceed as follows. In section 1, I will lay out the Normative Objection and Streumer's unbelievability defense against it. In section 2, I will very briefly sketch Streumer's main arguments for the Error Theory. In section 3, I lay out the Undermining Normative Objection in detail. I conclude in section 4 .

\section{THE NORMATIVE OBJECTION AND THE UNBELIEVABILITY RESPONSE}

Following Streumer's preferred reconstruction, we can understand the standard formulation of the Normative Objection along the following lines:

1. If a claim $C$ and a philosophical theory $T$ cannot both be true, and if $C$ is much more plausible than $T$, we should reject $T$.

2. The claim that we ought not to torture children for fun and the Error Theory cannot both be true.

3. The claim that we ought not to torture children for fun is much more plausible than the Error Theory.

Therefore:

4. We should reject the Error Theory. ${ }^{3}$

Streumer grants premises 2 and 3 , but denies premise 1 . The crucial problem with the premise, according to him, is that it overlooks an alternative explanation for the greater plausibility of $T$, other than $T$ 's most likely being false. ${ }^{4}$ Instead, our greater confidence in $C$ could also be explained by T's unbelievability. A theory that we cannot believe surely will not appear plausible to us, no matter whether it is false or not. All we can then safely assert is:

$1^{*}$. If a claim $C$ and a philosophical theory $T$ cannot both be true, and if $C$ is much more plausible than $T$, either it is the case that we should reject $T$, or $T$ is unbelievable.

This, in turn, only allows us to infer the following, weaker conclusion:

$4^{*}$. Either we should reject the Error Theory or the Error Theory is unbelievable.

As noted, I shall not challenge Streumer in his assumption that the Error Theory is unbelievable. ${ }^{5}$ This would then leave the Normative Objection without any

3 Streumer, Unbelievable Errors, 173-75.

4 Streumer, Unbelievable Errors, 176.

5 For pertinent criticism, see Olson, "On the Defensibility and Believability of Moral Error 
force against Streumer's version of the Error Theory. The Normative Objection does not give us any reason to reject the Error Theory, since the theory's unbelievability provides a suitable alternative explanation of its plausibility deficit.

Streumer's response to the Normative Objection turns fundamentally on the Unbelievability Thesis. His argument for this thesis proceeds from what he takes to be necessary conditions for the attitude of belief, conditions that Streumer holds could not be met by individuals convinced by the arguments for the Error Theory. ${ }^{6}$ The Unbelievability Thesis thus only applies to the encompassing version of the Error Theory that Streumer himself defends - an Error Theory about all normative judgments, including judgments about reasons for belief. ${ }^{7}$ As Streumer himself admits, we are able to believe narrower kinds of error theory, as long as these do not extend to all judgments about reasons for belief. ${ }^{8}$ These type of theories, like the classical Moral Error Theory defended by Mackie and by Joyce, are thus unable to avoid the Normative Objection in Streumer's way. ${ }^{9}$

Alexander Hyun and Eric Sampson pick up on this fact, and try to show how it comes back to haunt Streumer in the end:

Although we cannot believe the Error Theory, we can come close to believing the Error Theory, and Streumer has argued that we have reason to do so. Streumer recognizes that a way to come close to believing the Error Theory is to believe those theses that are parts of the Error Theory, and surely Moral Error Theory is a part of the Error Theory. So, if there are reasons to come close to believing the Error Theory, then there are reasons to believe Moral Error Theory, and as a result our deepest and most important moral convictions are indeed threatened. ${ }^{10}$

I think Hyun and Sampson have the right hunch here. However, they do not quite manage to put their finger on the precise way in which the possibility of believing the Moral Error Theory causes problems for Streumer. Streumer himself makes this clear in response.

The arguments [for the Error Theory] will make us believe a Moral Error

Theory"; and Forcehimes and Talisse, "Belief and the Error Theory."

6 See Streumer, Unbelievable Errors, ch. 9.

7 I will refer to this encompassing version as "the Error Theory" in what follows.

8 Streumer, Unbelievable Errors, 152.

9 Mackie, Ethics; Joyce, The Myth of Morality.

10 Hyun and Sampson, "On Believing the Error Theory," 640. 
Theory only if we mistakenly think that these arguments fail to apply to judgements about reasons for belief. ${ }^{11}$

Though Streumer does not quite make it explicit, I think his reasoning is as follows. There are a number of true premises which together, via intermediary conclusions, form a sound argument for the Error Theory. Since the Error Theory is unbelievable, however, they do not succeed in making us believe it. Nonetheless, the arguments are able to make us believe the individual intermediary conclusions supported by their premises. These are the "parts of the Error Theory" that the Error Theorist's arguments exert pressure on us to believe, since the relevant sub-arguments proceed only from believable premises to believable conclusions. Hyun and Sampson, however, seem to suggest that Streumer would be forced to believe a Moral Error Theory by reasoning like this:

1. The Error Theory is true.

2. If we cannot believe a true theory, we have reason to come close to believing it.

3. We can come close to believing the Error Theory by believing the Moral Error Theory.

Therefore:

4. We have reason to believe the Moral Error Theory.

Unlike the arguments supporting the intermediate conclusions, this case for believing the Moral Error Theory involves an unbelievable premise-the truth of the Error Theory. And since, as Streumer holds, arguments that turn on unbelievable propositions will not succeed in making us believe anything, he finds himself, pace Hyun and Sampson, under no pressure to come close to believing the Error Theory by believing a Moral Error Theory. ${ }^{12}$

However, there is a different, more efficient way to bring to bear the Normative Objection on the Error Theory via a detour through the Moral Error Theory. Instead of trying to give us reason to disbelieve the Error Theory as a whole, this objection systematically challenges the arguments in support of it. Before formulating it, however, I will have to briefly survey the general shape of the arguments that Streumer fields for the Error Theory.

\section{Streumer, Unbelievable Errors, 177.}

Furthermore, it is hard to see how an argument that relied on the truth of the Error Theory could ever entail that there is reason to believe the parts of the Error Theory that are believable, since, if the Error Theory were true, there would be no reason to believe anything. 


\section{STREUMER'S ARGUMENTS FOR THE ERROR THEORY}

In chapters 2 to 7 of Unbelievable Errors, Streumer puts forward three main lines of argument in defense of the Error Theory. Here is Streumer summarizing their upshots.

The reduction argument shows that

1. If there are normative properties, these properties are identical to descriptive properties,

and the false guarantee and regress objections show that

2. If there are normative properties, these properties are not identical to descriptive properties.

These claims together entail that normative properties do not exist. But the symmetry objection shows that

3. Normative judgements are beliefs that ascribe normative properties.

These three claims together entail that the Error Theory is true: they together entail that normative judgements are beliefs that ascribe normative properties, but that these properties do not exist. ${ }^{13}$

Streumer's endorsement of the Unbelievability Thesis lends these three lines of argument a slightly peculiar standing. As Streumer puts it, he believes they are "sound arguments that together seem to show that the Error Theory is true." ${ }^{14} \mathrm{He}$ hastens to clarify that this does not mean that the arguments are only seemingly sound. Nonetheless, they cannot lead us to believe that the Error Theory is true, because we can follow an argument to its conclusion only if that conclusion is believable. Nonetheless, the fact that the arguments are sound is crucial. Were there no sound arguments that together entailed the truth of the Error Theory, the theory would not only fail to be interesting, but we would most likely have reasons for believing that it is false, given its strongly counterintuitive implications.

\section{THE UNDERMINING NORMATIVE OBJECTION}

The soundness of the arguments just surveyed is what is challenged by the Un-

13 Streumer, Unbelievable Errors, 103-4.

14 Streumer, Unbelievable Errors, 153. 
dermining Normative Objection. To present this challenge, one need not consider the details of the arguments. What suffices, rather, is their general form. Here, then, is my argument:

1. The main argument for the Error Theory has the following general form:
a. All members of set $S$ are $x$, if they exist. ${ }^{15}$
b. All members of set $S$ are non- $x$, if they exist.
c. No members of set $S$ exist.

2. If an argument that has the aforementioned general form is sound, then there is a derivative argument with the following form that is also sound:
a'. All members of subset $S_{1}$ are $x$, if they exist.
$b^{\prime}$. All members of subset $S_{1}$ are non- $x$, if they exist.
c'. No members of subset $S_{1}$ exist.

3. If the main argument for the Error Theory is sound, then there is a derivative argument for the Moral Error Theory that is also sound. (From 1 and 2)

4. If there is a sound argument for the Moral Error Theory, then we should believe the Moral Error Theory.

5. If a claim $C$ and a philosophical theory $T$ cannot both be true, and if $C$ is much more plausible than $T$, either it is the case that we should reject $T$, or $T$ is unbelievable.

6. If the Moral Error Theory is true, then it cannot be true that we ought not to torture children for fun.

7. The claim that we ought not to torture children for fun is much more plausible than the Moral Error Theory.

8. We can believe the Moral Error Theory.

9. We should reject the Moral Error Theory. (From 5, 6, 7, and 8)

10. The derivative argument for the Moral Error Theory is not sound. (From 4 and 9)

11. Therefore, the argument for the Error Theory is not sound. (From 3 and 10)

This argument is clearly valid, since it employs only a simple succession of straightforward applications of modus ponens and modus tollens. Let me thus offer a few words on its premises. I believe premise 1 involves a fair reproduction of the general structure of Streumer's argument as laid out above. Premise

$15 S$ here being the set composed of all normative properties, and $x$ being [identical to a descriptive property]. 
2 appears impossible to deny, on pain of going against elementary logic. If we can disprove the existence of all members of a set by pointing to contradictory qualities all such members would have to have, then we can equally do so for members of a subset, since these necessarily share the same qualities. Applied to the case for the Error Theory, $S_{1}$ would then of course be the set of moral properties. Since these do indeed form a subset of the broader category of normative properties, the first intermediate conclusion, 3 , follows from 1 and $2 .{ }^{16}$

Premises 6, 7, and 8 are, as I have already mentioned above, all explicitly endorsed, or at least not rejected, in various places of Streumer's discussion of the Normative Objection. This leaves premises 4 and 5 as the only potential points of defense for the defender of the Error Theory.

One move that might immediately come to mind would be to qualify premise 4 in the same way that we qualified the first premise of the original Normative Objection above. We might say that there being a sound argument for the Moral Error Theory does not show that we should accept the Moral Error Theory, but merely that either it is so, or the theory is unbelievable. This however does not help the Error Theorist in the current situation. As Streumer acknowledges, it is not the case that the Moral Error Theory, one of the premises of the argument, or a combination of them is unbelievable. Even though the argument is structurally isomorphic, the premises of the argument proposed in 2 are independent of those involved in the case for the Error Theory. There is thus a set of true premises, all of which can be believed, which together entail a conclusion that can equally be believed.

The situation is rendered slightly more complicated by the fact that the derivative argument in premise 2 may not, after all, succeed in showing that people like Streumer himself, who also believe the premises of the argument for the Error Theory, should accept the Moral Error Theory. This is because these people may not be able to assess premises $\mathrm{a}^{\prime}, \mathrm{b}^{\prime}$, and $\mathrm{c}^{\prime}$ independently from $\mathrm{a}, \mathrm{b}$, and c. Therefore, they may not be able to follow the argument to its conclusion, since doing so would amount to (also) accepting the unbelievable Error Theory.

A caveat: I have been simplifying matters a bit by speaking of the main argument for the Error Theory. I have been hedging in this way because showing that normative properties do not exist is obviously not sufficient for a case for the Error Theory. One also needs to show (as Streumer attempts to) that normative judgments do actually ascribe these properties, in order to forestall non-cognitivist alternatives. This complication does not matter for my purposes here, however. If normative discourse on the whole is cognitive, then moral discourse, as a particular type of normative discourse, surely is as well. We can therefore safely assert, with 3, that if the argument for the Error Theory is sound, then there is a derivative argument for the Moral Error Theory that is also sound. 
Premise 4 thus may not be true as long as the "we" refers to those already convinced of Streumer's arguments.

But this fact does not rob the Undermining Normative Objection of its dialectical force. The point of the objection is not to show that actual defenders of the Error Theory such as Streumer are committed to believing implausible conclusions. Rather, it is to show that there is a problem with Streumer's argument for the Error Theory. His argument entails the soundness of the derivative argument for the Moral Error Theory, and the unbelievability defense simply is not available for this latter argument. Streumer owes us a different kind of explanation of what is wrong with this argument qua argument, irrespective of whether he himself can ultimately believe it. ${ }^{17}$ If such an explanation cannot be provided, then we are forced to conclude that Streumer's arguments for the Error Theory cannot be sound either, at least if we accept the presuppositions of the Normative Objection (i.e., 6, 7, and 8). ${ }^{18}$

\section{CONCLUSION}

As I have shown, Streumer's attempt to deflect the Normative Objection by appeal to the unknowability of the Error Theory fails. This is an important result. I take it that one of the most interesting features of Streumer's project of joining a case for the Error Theory with a defense of the Unbelievability Thesis is that it allows him to put forward his arguments for the Error Theory from a dialectically much more comfortable position. The Unbelievability Thesis, or so Streumer seems to think, allows us to engage in a carefree pursuit of a case for the Error Theory in its most radical form, without having to engage in many of the most

17 As an anonymous reviewer for JESP points out, a more serious problem for the Undermining Normative Objection would result if nobody was able to entertain $\mathrm{a}^{\prime}, \mathrm{b}^{\prime}$, and $\mathrm{c}^{\prime}$ without thereby coming to believe a, b, and c. It is true that if it were so, the defender of the Error Theory would have an out here. However, it seems to me that the underlying assumption does not stand up to scrutiny. Even though it is entailed by the original argument for the Error Theory, the derivative argument can solidly stand for itself: its premises a', b', and c' can be understood and justified without reference to $a, b$, and $c$. To make this clear by filling in the variables: a person can be convinced that moral properties, if they really existed, would have to be both identical to descriptive properties and not identical to descriptive properties, without thereby being led to believe anything about nonmoral (in particular: epistemic) normativity. This possibility is all that is required for the undermining normative objection to retain its force.

18 The Undermining Normative Objection of course does not tell us anything about where Streumer's arguments for the Error Theory go wrong, just that there has to be a flaw in them somewhere. For a recent attempt to identify problems in Streumer's argument, see Laskowski, "Reductivism, Nonreductivism, and Incredulity about Streumer's Error Theory." 
pressing objections traditionally fielded against it. If the Undermining Normative Objection as laid out above is sound, however, then Error Theorists such as Streumer cannot sit back and relax quite as early. At least one of the traditional objections against the Error Theory, and quite possibly the most formidable one, still is very much on the table even if we accept the Unbelievability Thesis. ${ }^{19}$

Humboldt University of Berlin
daniele.bruno@hu-berlin.de

\section{REFERENCES}

Dworkin, Ronald. "Objectivity and Truth: You'd Better Believe It." Philosophy and Public Affairs 25, no. 2 (Spring 1996): 87-139.

Forcehimes, Andrew T., and Robert B. Talisse. "Belief and the Error Theory." Ethical Theory and Moral Practice 19, no. 4 (February 2016): 849-56.

Hyun, Alexander, and Eric Sampson. "On Believing the Error Theory." Journal of Philosophy 111, no. 11 (November 2014): 631-40.

Joyce, Richard. The Myth of Morality. Cambridge: Cambridge University Press, 2001.

Laskowski, N. G. "Reductivism, Nonreductivism, and Incredulity about Streumer's Error Theory.” Analysis 78, no. 4 (October 2018): 766-76.

Mackie, J. L. Ethics: Inventing Right and Wrong. Harmondsworth: Penguin, 1977.

Nagel, Thomas. The Last Word. New York: Oxford University Press, 1997.

Olson, Jonas. Moral Error Theory. Oxford: Oxford University Press, 2014.

- "On the Defensibility and Believability of Moral Error Theory: Reply to Evers, Streumer, and Toppinen." Journal of Moral Philosophy 13, no. 4 (June 2016): 461-73.

Streumer, Bart. Unbelievable Errors. Oxford: Oxford University Press, 2017.

19 I would like to thank David Heering, Bart Streumer, and two anonymous referees for JESP for their helpful comments on earlier versions of this article. Work on this project has been supported by the Einstein Stiftung Berlin. 